\title{
Secondary organic aerosol formation during June 2010 in Central Europe: measurements and modelling studies with a mixed thermodynamic-kinetic approach
}

\author{
B. Langmann ${ }^{1}$, K. Sellegri ${ }^{2}$, and E. Freney ${ }^{2}$ \\ ${ }^{1}$ Institute of Geophysics, University of Hamburg, KlimaCampus, Hamburg, Germany \\ ${ }^{2}$ Laboratoire de Météorologie Physique, CNRS, Université Blaise Pascal Aubière, France \\ Correspondence to: B. Langmann (baerbel.langmann@zmaw.de)
}

Received: 28 August 2013 - Published in Atmos. Chem. Phys. Discuss.: 15 October 2013

Revised: 18 March 2014 - Accepted: 19 March 2014 - Published: 16 April 2014

\begin{abstract}
Until recently secondary organic carbon aerosol (SOA) mass concentrations have been systematically underestimated by three-dimensional atmospheric-chemistryaerosol models. With a newly proposed concept of aging of organic vapours, more realistic model results for organic carbon aerosol mass concentrations can be achieved. Applying a mixed thermodynamic-kinetic approach for SOA formation shifted the aerosol size distribution towards particles in the cloud condensation nuclei size range, thereby emphasising the importance of SOA formation schemes for modelling realistic cloud and precipitation formation. The additional importance of hetero-molecular nucleation between $\mathrm{H}_{2} \mathrm{SO}_{4}$ and organic vapours remains to be evaluated in three-dimensional atmospheric-chemistry-aerosol models. Here a case study is presented focusing on Puy-de-Dôme, France in June 2010. The measurements indicate a considerable increase in SOA mass concentration during the measurement campaign, which could be reproduced by modelling using a simplified thermodynamic-kinetic approach for SOA formation and increased biogenic volatile organic compound (VOC) precursor emissions. Comparison with a thermodynamic SOA formation approach shows a huge improvement in modelled SOA mass concentration with the thermodynamic-kinetic approach for SOA formation. SOA mass concentration increases by a factor of up to 6 accompanied by a slight improvement of modelled particle size distribution. Even though nucleation events at Puy-de-Dôme were rare during the chosen period of investigation, a weak event in the boundary layer could be reproduced by the model in a sensitivity study when nucleation of low-volatile secondary
\end{abstract}

organic vapour is included. Differences in the model results with and without nucleation of organic vapour are visible in the lower free troposphere over several days. Taking into account the nucleation of organic vapour leads to an increase in accumulation mode particles due to coagulation and condensational growth of nucleation and Aitken mode particles.

\section{Introduction}

Measurements of the chemical composition of atmospheric aerosol indicate a contribution of organic carbon aerosol (OA) ranging from 20 to $70 \%$ to the submicron particulate matter mass (Jimenez et al., 2009). Primary organic carbon aerosols (POAs) are directly emitted into the atmosphere whereas secondary organic carbon aerosols (SOAs) are formed by atmospheric oxidation of organic vapours (here called secondary organic gases: SOGs). SOA makes up between 36 and $80 \%$ of the total OA concentration of atmospheric aerosol worldwide (Jimenez et al., 2009). Until recently, atmospheric models systematically underestimated measured OA mass concentrations in the atmosphere by a factor of up to 10 and more (e.g. Heald et al., 2005; Marmer and Langmann, 2007; Jimenez et al., 2009; Yu, 2011). This underestimation is partly due to a lack of understanding of SOA formation mechanisms with the large number of different organic compounds involved (e.g. Griffin et al., 2002; Kroll and Seinfeld, 2008; Hallquist et al., 2009), and has hindered an adequate implementation into three-dimensional atmospheric-chemistry-aerosol models until today. 
In contrast to SOA formation, sulfate formation takes place through oxidation of $\mathrm{SO}_{2}$ followed by either irreversible condensation of sulfuric acid molecules on preexisting particles or nucleation to form new particles. The formation of SOA is much more complex due to the semivolatile nature of the precursor gas phase species and the enormous number of different organic compounds involved. The widely used thermodynamic two-product approach of gas-particle partitioning between semi-volatile organic compounds in the gas phase and the aerosol phase according to Henry's law (Pankow, 1994; Odum et al., 1996) was found to be insufficient in reproducing measured SOA concentrations (Yu, 2011). Taking into account more precursor gases, e.g. isoprene (e.g. Henze and Seinfeld, 2006), increases modelled SOA mass concentrations, but the general underestimation remains. As already pointed out by Heald et al. (2005) and references therein and later by Robinson et al. (2007) and Shrivastava et al. (2008), successive generation of oxidation products following the first stage of oxidation of emitted hydrocarbons may increase the condensable amount of organic vapours thereby producing higher SOA mass concentrations. Jimenez et al. (2009) proposed the concept of aging of organic vapours, thereby producing less volatile and higher oxygenated organic vapours which can generate atmospheric SOA mass concentrations comparable to sulfate. Based on these ideas several recent studies have considered the aging of organic vapours and/or aerosols based on thermodynamic partitioning (e.g. Hodzic et al., 2010; Shrivastava et al., 2011; Bergström et al., 2012). Yu (2011) developed another promising modelling strategy for the formation of SOA considering the aging of SOG. In addition to the traditional two-product thermodynamic gas-particle partitioning of a number of parent compounds, Yu et al. (2011) introduced a third low volatile organic compound (LV-SOG), which kinetically undergoes condensation on pre-existing particles. This is a major difference to the widely applied thermodynamic approaches. It was shown that modelled annual mean SOA mass concentrations increased by a factor of 2-20 in many parts of the boundary layer worldwide (Yu, 2011). In addition, the modelled aerosol size distribution shifted from particles less than $10 \mathrm{~nm}$ to those of the size of cloud condensation nuclei (about $50-100 \mathrm{~nm}$ ). This highlights the importance of reliable SOA formation mechanism for more realistic model simulation results concerning clouds and precipitation formation.

Furthermore, the role of low volatile organic vapours in new particle formation in addition to $\mathrm{H}_{2} \mathrm{SO}_{4}$ nucleation has received increasing attention in recent years. It has been demonstrated that $\mathrm{H}_{2} \mathrm{SO}_{4}$ nucleation alone cannot always adequately explain observed particle number concentrations and size distributions (e.g. Fiedler et al., 2005; Hamed et al., 2010; Kerminen et al., 2010; Metzger et al., 2010; Paasonen et al., 2010).

Based on the approach developed by Yu (2011) we extended the SOA formation mechanism of the regional three- dimensional atmosphere-chemistry-aerosol model REMOTE (Langmann et al., 2008; Anttila et al., 2010). We implemented even more generalised assumptions than Yu (2011) for easy use in regional or global chemistry transport models or on-line atmosphere-chemistry-aerosol models. Different to $\mathrm{Yu}$ (2011) we consider also the contribution of anthropogenic SOG to SOA formation and include the nucleation of low-volatile SOG in a sensitivity study. The model set-up and the SOA formation scheme are described in Sect. 2. Section 3 describes a measurement campaign at Puy-de-Dôme, France in June 2010, which provides a set of measurements used to evaluate the model results presented in Sect. 4. The last section provides conclusions and an outlook.

\section{Model description}

\subsection{Model set-up}

We use the regional three-dimensional on-line climatechemistry-aerosol model REMOTE (Regional Model with Tracer Extension; Langmann, 2000; Langmann et al., 2008). REMOTE has been developed and applied to understand the dispersion and photochemical transformation of anthropogenic and natural gaseous and aerosol emissions (e.g. Langmann et al., 2003, 2008). The dynamical part of the model is based on the former regional weather forecast system of the German Weather Service (Majewski, 1991), which uses a hydrostatic assumption for the vertical pressure gradient. In addition to the German Weather Service physical parameterisations, those of the global climate model ECHAM4 (Roeckner et al., 1996) have been implemented in REMOTE and are used for the current study.

The domain is subdivided into $81 \times 91$ grid boxes of $0.5^{\circ}$ resolution (approximately $55 \mathrm{~km}$ ) on a rotated latitude/longitude grid with 19 vertical layers of increasing thickness between the earth surface and the $10 \mathrm{hPa}$ pressure level using terrain following hybrid pressure-sigma coordinates. A model time step of $5 \mathrm{~min}$ is chosen. REMOTE is initialised using meteorological analysis data of the European Centre for Medium-Range Weather Forecasts (ECMWF), which are updated at the lateral model boundaries every $6 \mathrm{~h}$ with linear interpolation in between. The model is started at 00:00 UTC every day to compute a $30 \mathrm{~h}$ meteorological forecast. The first $6 \mathrm{~h}$ of the consecutive meteorological forecasts are neglected to account for a spin-up time. The total simulation period is therefore composed of $24 \mathrm{~h}$ simulation segments with a discontinuity in the physical state of the atmosphere at 06:00 UTC. But, by starting the model again every day the internal model variability is suppressed and the model is forced to stay close to the observed weather situation. Aerosol and atmospheric chemistry processes, however, are calculated continuously. This is done by simulating meteorology only in the first $6 \mathrm{~h}$ of each $30 \mathrm{~h}$ forecast. Then, combined chemistry, aerosol and meteorology calculations 
continue for $24 \mathrm{~h}$ starting with the aerosol and atmospheric chemistry information from the last time step of the previous forecast. The prognostic equations for surface pressure, temperature, specific humidity, cloud water, horizontal wind components and aerosol mass mixing ratios are written on an Arakawa C-grid.

For the determination of aerosol dynamics and thermodynamics we use the M7 module, which is described in detail in Vignati et al. (2004) and Langmann et al. (2008). The aerosol dynamical processes in the standard M7 include nucleation, coagulation and condensation. The five aerosol components considered in the standard M7 are sulfate, black carbon, organic carbon, sea salt, and mineral dust. For the current application of the REMOTE model over Europe, mineral dust is not considered. The aerosol size spectrum is represented by the superposition of seven log-normal distributions subdivided into a soluble and an insoluble coarse, accumulation and Aitken mode, and an additional soluble nucleation mode. Photochemical production and loss in REMOTE is determined by the RADM II chemical scheme (Stockwell et al., 1990) including a wide range of hydrocarbon degradation reactions. Photolysis rates are calculated based on Madronich (1987). Aqueous phase chemistry processes are implemented according to Walcek and Taylor (1986).

After being released in the atmosphere, gas phase and aerosol phase species undergo transport processes (horizontal and vertical advection - Smolarkiewitz, 1983; transport in convective clouds - Tiedtke, 1989; vertical turbulent diffusion - Mellor and Yamada, 1974) and are removed from the atmosphere by sedimentation, dry and wet deposition. Dry deposition fluxes for gaseous compounds are determined after Wesley (1989). For aerosol particles, the same size-dependent parameterisations as in the ECHAM5-HAM model (Stier et al., 2005) are used for dry deposition and sedimentation. Wet deposition is computed according to Walcek and Taylor (1986) by integrating the product of the gridaveraged precipitation rate and the mean cloud water concentration which is determined from cloud base (first layer above the surface containing more than $0.001 \mathrm{~g} \mathrm{~kg}^{-1}$ liquid water) to cloud top (highest level exceeding an amount of $0.001 \mathrm{~g} \mathrm{~kg}^{-1}$ liquid water) for fair weather clouds and from the surface to cloud top for raining clouds. Scavenging is treated independent of size with scavenging efficiencies based on Kasper-Giebl et al. (2000) distinguishing between soluble and insoluble aerosols dependent on cloud liquid water content. In-cloud produced sulfate is distributed to the available pre-existing accumulation and coarse mode aerosol particles according to the respective number concentration (Stier et al., 2005).

\subsection{SOA formation scheme}

The standard M7 aerosol scheme (Vignati et al., 2004) has been extended by Anttila et al. (2010) by a thermodynamic two-compound SOA formation mechanism to con-

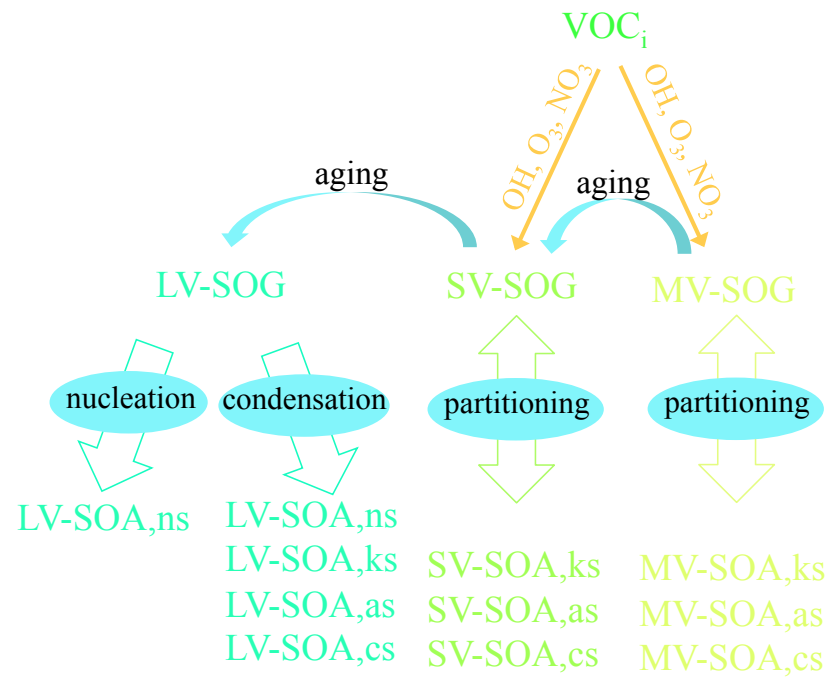

Fig. 1. Schematic illustration of SOA particle formation and oxidation aging processes. $\mathrm{VOC}_{i}$ : precursor gases; SOG: secondary organic gas; SOA: secondary organic aerosol; LV: low volatile; SV: semi-volatile; MV: medium volatile; ns: nucleation mode soluble; ks: Aitken mode soluble; as: accumulation mode soluble; cs: coarse mode soluble.

sider isoprene oxidation products for SOA formation. In accordance with the M7 aerosol scheme described above, the two SOA components (medium- and semi-volatile SOA) may be formed in the soluble Aitken, accumulation and coarse mode so that in total six new aerosol tracers have been implemented by Antilla et al. (2010). We extended the SOA formation scheme of Antilla et al. (2010) from the pure thermodynamic approach to a mixed thermodynamic-kinetic one including aging of SOG (Fig. 1) based on Yu (2011).

For the formation of medium- and semi-volatile SOG (MV-SOG and SV-SOG), we consider all chemical reactions of hydrocarbons and oxygenated hydrocarbons (e.g. acetaldehyde) with $\mathrm{OH}, \mathrm{NO}_{3}$ and $\mathrm{O}_{3}$ of the RADM-II photochemical mechanism (Stockwell et al., 1990). The formation of MV-SOG and SV-SOG is determined according to the prescribed yields and Henry's law constants (Table 1, modified from Anttila et al., 2010) based on the physico-chemical properties of 1,3-propanediol for MVSOG and 1,2,4-butanetriol for SV-SOG (Saxena and Hildemann, 1996).

We consider aging of the MV-SOG to SV-SOG and further aging of SV-SOG to low-volatile SOG (LV-SOG), with the latter compound being newly introduced into REMOTE. Aging is assumed to occur via $\mathrm{OH}$-oxidation with $k=3 \times 10^{11} \mathrm{~cm}^{3}$ molecules ${ }^{-1} \mathrm{~s}^{-1}$ according to Jimenez et al. (2009). As in $\mathrm{Yu}$ (2011), the loss of $\mathrm{OH}$ radicals by oxidation aging of SOG is ignored. To further simplify the approach of $\mathrm{Yu}$ (2011) we determine the massconserving transformation rate of $\mathrm{MV}$-SOG $\Rightarrow \mathrm{SV}$-SOG and $\mathrm{SV}-\mathrm{SOG} \Rightarrow$ LV-SOG by prescribing a maximum threshold of 
Table 1. Properties of medium- and semi-volatile secondary gases (MV-SOG and SV-SOG) based on Anttila et al. (2010). Note that the Henry's law coefficient for MV-SOG has been increased by one order of magnitude

\begin{tabular}{lrrr}
\hline Compound & $\begin{array}{r}\text { Stoichiometric } \\
\text { coefficients }\end{array}$ & $\begin{array}{r}\text { Molecular } \\
\text { weight }\left(\mathrm{g} \mathrm{mol}^{-1}\right)\end{array}$ & $\begin{array}{r}K_{\mathrm{H}} 298 \mathrm{~K} \\
\left(\mathrm{M} \mathrm{atm}^{-1}\right)\end{array}$ \\
\hline MV-SOG & 0.28 & 76.1 & $9.1 \times 10^{6}$ \\
SV-SOG & 0.032 & 106.0 & $3 \times 10^{11}$ \\
\hline
\end{tabular}

the reactant concentration being available for oxidation. The reason for the implementation of thresholds is a conceptual one. It has been introduced into the model to take into account that only a fraction of the respective SOGs will reach saturation vapour pressures low enough to move into the next lower volatility category (MV-SOG into SV-SOG and SVSOG into LV-SOG). As the oxidation products are represented by only one component in each category of the model, in this way the spread of saturation vapour pressures of different oxidation products is implicitly considered. Results with $1 \%$ and $10 \%$ threshold values (in the latter case an additional requirement is that $\mathrm{OH}$ concentrations exceed $0.1 \mathrm{ppt}$ thereby excluding night-time aging processes) are compared in Sect. 4.2 with measurements thereby empirically pointing to a reasonable threshold value of $10 \%$. In this way we avoid determining the saturation vapour pressure of the oxidised SOG compounds, which greatly simplifies the procedure proposed by Yu (2011). However, it should be emphasised that the optimal maximum threshold value may be variable in time and space so that an application to different locations and seasons requires further evaluation. The quasi-equilibrium assumption for SOG oxidation as applied in Anttila et al. (2010) is no longer valid when oxidation aging is considered. Therefore, in the current version the three SOG components are also subject to transport and removal processes.

LV-SOG is assumed to condense kinetically on preexisting particles, while for MV-SOG and SV-SOG the thermodynamic partitioning approach of Anttila et al. (2010) is used as shown in Fig. 1. In addition, nucleation of LVSOG is considered, so that in total four new LV-SOA components have been added to the model. In a sensitivity study in Sect. 4, LV-SOG nucleation and kinetic condensation is treated in the same way as $\mathrm{H}_{2} \mathrm{SO}_{4}$ in the $\mathrm{M} 7$ module (Stier et al., 2005; Vignati et al., 2004). As condensation on preexisting particles and nucleation of new particles compete for the available LV-SOG, first the maximum amount of condensable LV-SOG on pre-existing particles is calculated. The remaining LV-SOG is available for the nucleation of new clusters. The number of nucleated particles and the mass of nucleated LV-SOG is determined using the homogeneous nucleation parameterisation of Vehkamäki et al. (2002). The simple assumption applied in the current paper is to use the scheme of Vehkamäki et al. (2002) for two nucleation pathways: (1) $\mathrm{H}_{2} \mathrm{SO}_{4}+\mathrm{H}_{2} \mathrm{O}$ nucleation and (2) $\mathrm{LV}-\mathrm{SOG}+\mathrm{H}_{2} \mathrm{O}$ nucleation. For the second pathway $\mathrm{H}_{2} \mathrm{SO}_{4}$ concentrations are replaced by LV-SOG concentrations in the nucleation scheme. This approach should be understood as a zero-order approximation to conduct sensitivity studies, as experimental evidence for interactions between $\mathrm{LV}$-SOG and $\mathrm{H}_{2} \mathrm{SO}_{4}$ is not considered and no adaptations for LV-SOG have been incorporated into the scheme of Vehkamäki et al. (2002). Future studies with REMOTE should consider interactions between LV-SOG and $\mathrm{H}_{2} \mathrm{SO}_{4}$ as proposed by Kerminen et al. (2010), Metzger et al. (2010) and Paasonen et al. (2010).

\subsection{Emissions}

Anthropogenic emissions of $\mathrm{SO}_{\mathrm{x}}, \mathrm{NO}_{\mathrm{x}}, \mathrm{NH}_{3}, \mathrm{CO}$, volatile organic compounds (VOCs) and $\mathrm{PM}_{2.5}$ obtained from the EMEP emission inventory (http://www.ceip.at/) are prescribed as monthly fluxes as outlined in Marmer and Langmann (2007). In addition to anthropogenic emissions, terrestrial biogenic terpene and isoprene emissions from forests are considered based on Guenther et al. (1991, 1993). Marine POA emissions are determined following O'Dowd et al. (2008) and Gantt et al. (2011). Further details of the treatment of primary anthropogenic aerosol emissions and marine sea-spray emissions are described in Langmann et al. (2008).

\section{Measurement campaign}

During June 2010, a 2-week intensive measurement campaign (21 June-4 July) took place at Puy-de-Dôme, France approximately $10 \mathrm{~km}$ away from Clermont-Ferrand. Puy-deDôme ( $45^{\circ} 46^{\prime} \mathrm{N} 02^{\circ} 57^{\prime} \mathrm{E}$; $1464 \mathrm{~m}$ a.s.l.) is a large lava dome and one of the youngest volcanoes in the Chaine des Puys region of Massif Central in south-central France.

The principal goals of the measurement campaign were to evaluate aerosol size distribution and chemistry in the boundary layer and lower free troposphere but also to characterise aerosol early growth dynamics during new particle formation events at high altitude. In addition to a number of online and offline instrumentation, aerosol size distribution was measured using a scanning mobility particle sizer (SMPS), selecting particles diameters between 30 and $500 \mathrm{~nm}$ with a time resolution of $120 \mathrm{~s}$. Aerosol chemical composition and mass concentration of the non-refractory submicron particulate matter was measured with an Aerodyne time-of-flight aerosol mass spectrometer (C-ToF-AMS) (Drewnick et al., 2005; Canagaratna et al., 2007). The C-ToF-AMS was sampling behind a whole air inlet during the cloud-free period after 22 June. In the period 20-22 June, when cloudy conditions prevail at Puy-de-Dôme, C-ToF-AMS was sampling behind an interstitial inlet. More detailed description of the C-ToF-AMS set-up and results during measurement campaigns at the Puy-de-Dôme site in 2008, 2009 and 2010 are 
available in Freney et al. (2011). The resolved mass concentrations include ammonium, sulfate, nitrate, organic carbon and chloride species. In order to extract chemically resolved mass concentrations of individual aerosol species, the C-ToF-AMS raw data are evaluated with standard assumptions as described by Allan et al. (2004). The organic carbon aerosol mass contributed up to $56 \%$ to the total aerosol mass and increased gradually with temperature. Positive matrix factorisation analysis of the organic aerosol separated a low-volatile and a semi-volatile oxidised organic aerosol.

\section{Model results and comparison with observations}

\subsection{Meteorological conditions}

The week before the 2-week intensive measurement campaign (21 June-4 July) at Puy-de-Dôme, France was characterised by heavy rainfall events and day-time temperatures well below $20^{\circ} \mathrm{C}$ in many parts of western Europe. The coldest day was the mid-summer day where even freezing at ground level was measured locally. During the first measurement campaign week, temperatures increased all over Europe due to the build-up of a high-pressure system, which lasted until the end of the measurement campaign in early July 2010. Precipitation was not measured in the Puy-deDôme area after 20 June, whereas the model determines small amounts of precipitation on 24 June and a convective precipitation event on $28 / 29$ June. In this context it should be considered that model results are produced in $0.5^{\circ}$ resolution, thereby representing average conditions for a larger area than Puy-de-Dôme alone. Measured and modelled temperature and relative humidity at Puy-de-Dôme during June 2010 are displayed in Fig. 2. Model results are shown for the first and second model layer. This is done because the measurement location with the peak of Puy-de-Dôme is not resolved by the model's horizontal resolution of $0.5^{\circ}$. In the following sections, model simulation results focusing on the first model layer will be presented. Altogether, REMOTE model simulation results during June 2010 around Puy-de-Dôme reproduce satisfactorily the observed meteorological situation.

\subsection{Atmospheric aerosol concentrations}

\subsubsection{Aerosol mass concentration}

Sulfate and chlorine aerosol mass concentrations at Puyde-Dôme are well captured in the model simulation results (Fig. 3), although sulfate concentrations are generally underestimated. Sulfate formation is limited by the availability of oxidants rather than $\mathrm{SO}_{2}$ and is therefore in competition with other oxidation processes. For chloride, only the modelled accumulation mode concentration is displayed in Fig. 3, as AMS does not capture coarse mode particles. Modelled chloride mass concentrations including coarse and accumulation mode chloride reaches a maximum concentration of
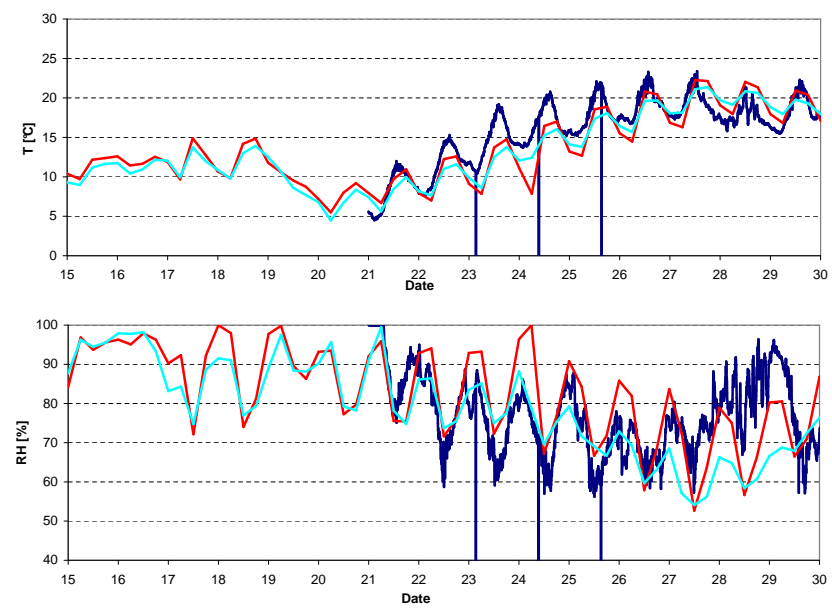

Fig. 2. Meteorological situation at Puy-de-Dôme during June 2010. (a) Temperature $\left[{ }^{\circ} \mathrm{C}\right]$, (b) relative humidity [\%]. Dark blue line: measurements, red line: model results first layer, light blue line: model results second layer.
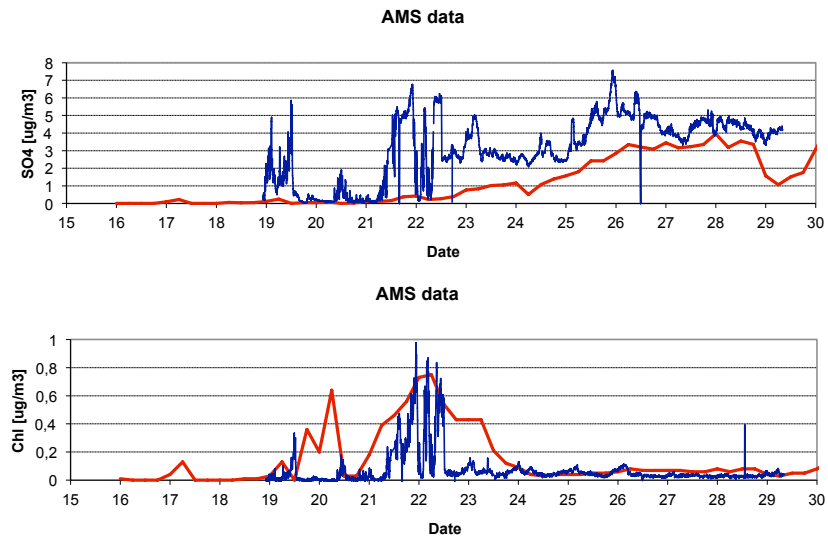

Fig. 3. AMS-measured (dark blue line) and modelled (red line) near-surface aerosol mass concentration during June 2010 at Puyde-Dôme, France. (a) Sulfate $\left[\mu \mathrm{g} \mathrm{m}^{-3}\right]$, (b) chloride $\left[\mu \mathrm{g} \mathrm{m}^{-3}\right]$.

$17 \mu \mathrm{g} \mathrm{m}^{-3}$ on 22 June. These peak concentrations are connected to the transport of marine air masses, which are reported to contribute to more than $25 \%$ of all air masses arriving at Puy-de-Dôme during the summer months (Venzac et al., 2009). It should be emphasised again that the AMS measurements on 20-22 June were made under cloudy conditions behind an interstitial inlet (see Sect. 3) restricting the sampling in comparison to the whole air inlet, which was used during the following campaign days. In addition, submicron chloride originating from sea salt is only partially detected by the AMS due to its high volatilisation temperature (Ovadnevaite et al., 2012), but the exact fraction is not known for the measurements presented here.

The measured organic carbon aerosol mass concentration is shown in Fig. 4 (dark blue line). In order to illustrate the sensitivity of OA model results on SOA parameterisations, 


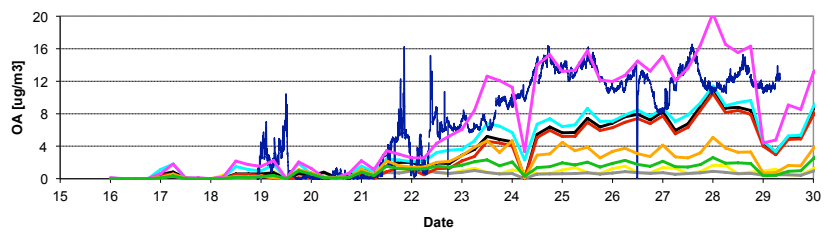

Fig. 4. AMS-measured (dark blue line) and modelled near-surface SOA mass concentration during June 2010 at Puy-de-Dôme, France. Grey line: according to Anttila et al. (2010); yellow line: more VOC precursor gases; green line: SOG transport and removal; orange line: SOG transport and removal plus biogenic emissions $\times 5$; red line: 1 . aging SOG $-1 \%$ aging; black line: 2 . aging SOG $-1 \%$ aging, light blue line: 2 . aging SOG - $10 \%$ aging; magenta line: 2 . aging SOG $-10 \%$ aging plus biogenic emissions $\times 5$. See the text for more explanation.

Fig. 4 shows the results for the original two-compound thermodynamic approach for isoprene only by Anttila et al. (2010) (grey line) and model results with additional VOC precursor gases (yellow line). Although a slight increase in OA mass concentration takes place, the model results are still far below the measurements. Taking into account SOG as additional prognostic trace species in the model, which undergo transport and removal (green line), leads to a slight but still insufficient increase in comparison with the measurements. This underestimation of modelled mass concentrations remains even in a sensitivity study where in addition to transport and removal of SOG, biogenic VOC emissions are increased by a factor of 5 due to their overall uncertainty (orange line). The red line in Fig. 4 shows results from the simulation where aging of MV-SOG to SV-SOG has been considered, generating OA mass concentrations approaching the measurements. Taking into account the aging of SV-SOG to LV-SOA (second aging step, black line) does not modify OA mass concentrations much in comparison to the first aging step. A further increase in OA mass concentration is achieved by assuming $10 \%$ (light blue line in Fig. 4) instead of $1 \%$ of aging (see Sect. 2.2). Increasing the amount of biogenic VOC emissions by a factor of 5 in the $10 \%$ aging simulation leads to a considerable increase in OA mass concentrations (up to a factor of 6) in the range of the measurements. SOA mass concentration remains nearly unchanged taking into account the nucleation of LV-SOA. The reasons lie in the absence of nucleation events in the boundary layer during the high-pressure period. Further discussion on the role of SOA nucleation is presented in a sensitivity study in Sect. 4.2.2.

The reduction of modelled OA mass concentration on 24 June is connected to small amounts of modelled stratiform precipitation. Similarly, the modelled OA mass concentration is reduced again on 28/29 June as a result of a convective precipitation event determined by the model. The increase of SOA concentrations throughout the high-pressure period was not restricted to Puy-de-Dôme but took place over large parts of Europe (Fig. 5) with concentrations greatly exceed-
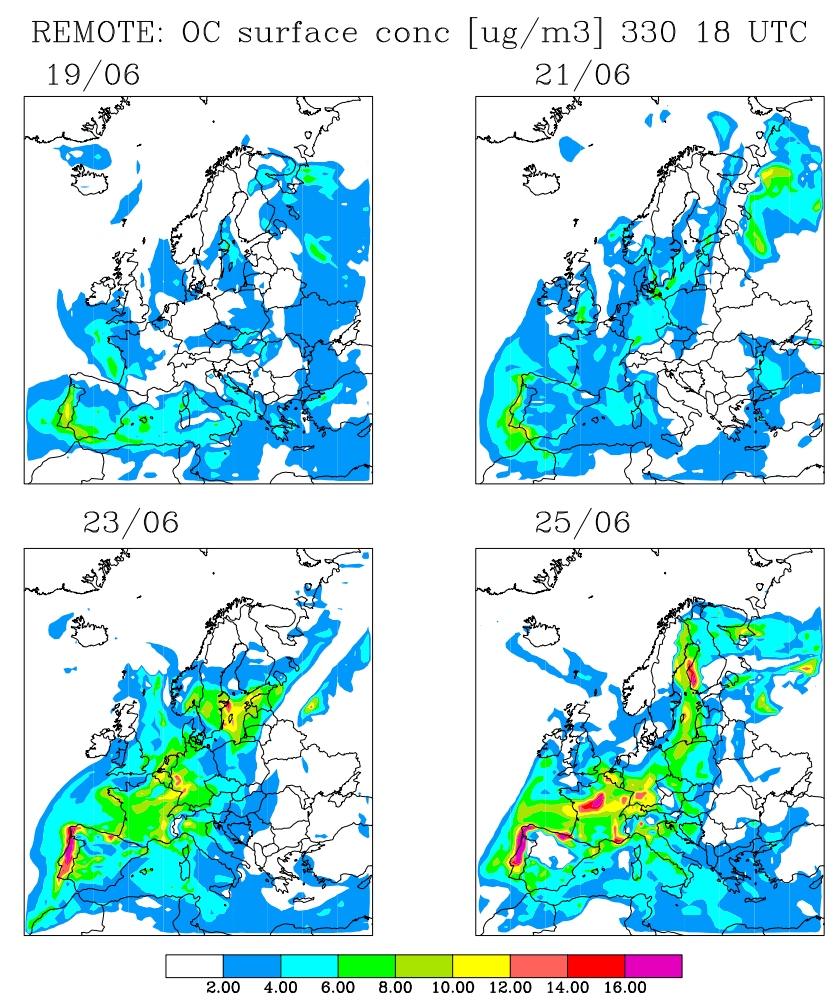

Fig. 5. Modelled near-surface concentration of organic carbon aerosol in $\mu \mathrm{g} \mathrm{m}^{-3}$ on 19, 21, 23 and 25 June at 18:00 UTC by considering the second aging of SOG and a threshold of $10 \%$ for aging. Model simulation results correspond to those shown by the light blue line in Fig. 4.

ing $5 \mu \mathrm{g} \mathrm{m}^{-3}$. A diurnal cycle in observed OA concentration is nearly invisible.

Applying different thresholds for the available SOG for aging, e.g. $1 \%$ or $10 \%$, respectively, modified the amount of semi-volatile SOA (note that here the sum of modelled MV-SOA and SV-SOA is meant) and LV-SOA considerably (Fig. 6). Assuming $1 \%$ of aging overestimates the amount of semi-volatile SOA, which in this case consists mainly of MVSOA. The limited amount of SV-SOG at $1 \%$ aging results in an underestimation of LV-SOA. Assuming $10 \%$ of aging when $\mathrm{OH}$ concentrations exceeds 0.1 ppt leads to much better agreement between modelled and measured semi-volatile SOA and LV-SOA. See supplement (Fig. S1 and associated text) for concentration time series of $\mathrm{H}_{2} \mathrm{SO}_{4}$ (gas), MVSOG, SV-SOG and LV-SOG during June 2010 at Puy-deDôme. A further increase to $50 \%$ aging shows no considerable effects for semi-volatile SOA and LV-SOA. It should be noted that from C-ToF-AMS measurements oxidised organic aerosol (OOA) concentrations are determined, which we equate with modelled SOA concentrations. In addition, C-ToF-AMS measurements may include aged POA, however at Puy-de-Dôme, this contribution was not separated from SOA. 

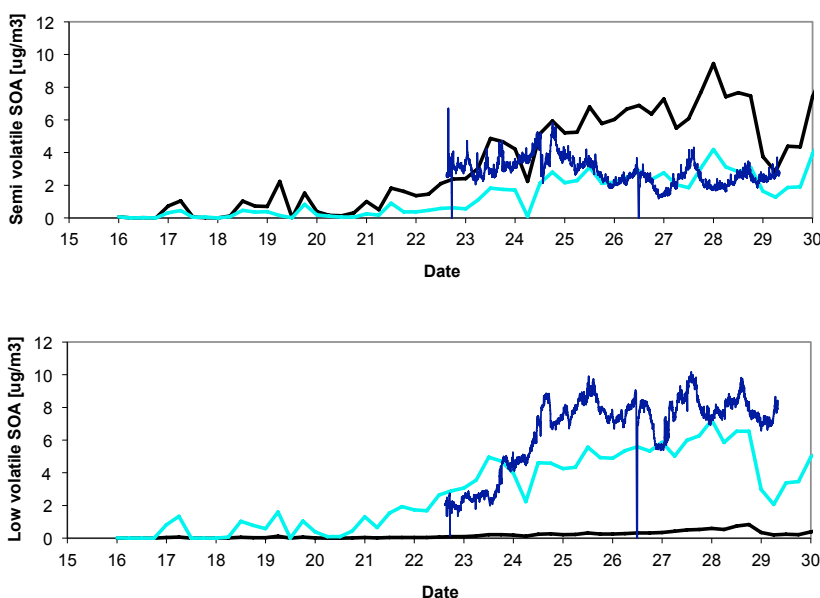

Fig. 6. Near-surface SOA aerosol mass concentration during June 2010 at Puy-de-Dôme, France. (a) Semi-volatile SOA, (b) lowvolatile SOA. Dark blue line: AMS-measured, black line: 2 . aging SOA $-1 \%$ aging, light blue line: 2 . aging SOA $-10 \%$ aging. Modelled LV-SOA is compared to measured low-volatile SOA and the modelled sum of MV-SOA and SV-SOA is compared to measured semi-volatile SOA. Model simulation results correspond to those shown as black and light blue lines in Fig. 4.

To extend the evaluation of the applied SOA formation scheme, further model simulations over Europe for different periods (January 2003, June 2003) were conducted for comparisons with data presented in Langmann et al. (2008). During June 2003 a considerable improvement in modelled OA mass concentrations over Europe could be achieved with the SOA formation scheme described here (Supplement Fig. S2). However, during winter conditions in January 2003, improvements of model OA concentrations were not achieved, indicating further deficiencies. See Sect. 5 for more discussions.

\subsubsection{Aerosol size distribution, number concentration and nucleation}

Although SOA mass concentration remains nearly unchanged when taking into account the second aging step in addition to the first aging step (Fig. 4), it should be noted that considerable differences in the aerosol size distribution are determined between these two model simulations and the pure thermodynamic approach. Figure 7 compares the modelled size distribution in the near-surface fresh (20, 21 June) and aged (26, 27 June) air masses at Puy-de-Dôme for the pure thermodynamic approach (corresponding to the green line in Fig. 4) and for the first aging step (corresponding to the red line in Fig. 4, however with $10 \%$ aging) against the mixed thermodynamic-kinetic approach (corresponding to the light blue line in Fig. 4). The measurements indicate a considerable increase in aerosol number concentration of accumulation mode particles in the period 20-27 June, 2010 by more than $5000 \mathrm{~cm}^{-3}$ accompanied by a considerable decrease of Aitken mode particles of about $7000 \mathrm{~cm}^{-3}$. It should be noted, however, that only interstitial particles were measured before 23 June (see Sect. 3). Considering that the model applies a modal approach for the size distribution, it can satisfactorily reproduce the measurements in the fresh air masses although the modelled absolute number concentration is smaller than the observed one. Aged air masses show a considerable increase in modelled particle number concentration of accumulation mode particles. Different to the observations, modelled Aitken mode particle number concentration increases as well in the period 20-27 June. The reason is the emission of primary $\mathrm{OA}$ and $\mathrm{BC}$ aerosols released into the insoluble Aitken mode in the first model layer, which accumulates in the PBL (planetary boundary layer), in particular in the surface layer during night-time. However, the Puy-de-Dôme measurement location is in the residual layer above the surface layer during night-time. Therefore, nighttime data have been excluded from the model data analysis in Fig. 7. Nevertheless, an overestimation of Aitken mode particle number concentration remains. Again, it should be noted here that the model resolution of $0.5^{\circ}$ is too coarse to accurately reproduce the special conditions at Puy-de-Dôme.

In the fresh air masses, the pure thermodynamic approach shows more particles in the Aitken mode than the thermodynamic-kinetic approach, similar to previous findings (Yu, 2011; Riipinen et al., 2011; Zhang et al., 2012; D'Andrea et al., 2013). With the thermodynamic-kinetic approach a faster growth to accumulation mode particles takes place during the aging process. In the aged air masses, the differences are much smaller, however a determination of bigger particles remains with the thermodynamic-kinetic approach. Considering only the first aging step for SOA formation results in an increase of SV-SOG as further consumption for LV-SOG formation is excluded. Gas-particle partitioning of SV-SOG is the major reason for the shift in the mode radii. Due to the thermodynamic equilibrium assumptions, the irreversible growth of the Aitken mode particles into the accumulation mode is not allowed in this case, so that accumulation mode particle number concentration increases at a slower rate during aging compared to the thermodynamickinetic approach. Generally, the thermodynamic-kinetic approach can more realistically reproduce the observed data than the pure thermodynamic approach, in particular in fresh air masses. Due to the model resolution of $0.5^{\circ}$, care must be taken when comparing modelled data representative for $250 \mathrm{~km}^{2}$ with a single station location. Therefore, particle number concentrations in near-surface air masses all over Europe are displayed in Fig. 8, showing that the differences between the thermodynamic approach and the thermodynamickinetic approach are not restricted to Puy-de-Dôme, but occur over large areas of Europe. This confirms the analysis of Henne et al. (2010) that measurements at Puy-de-Dôme are generally representative for a larger area and therefore suitable for the evaluation of European scale models. In the 

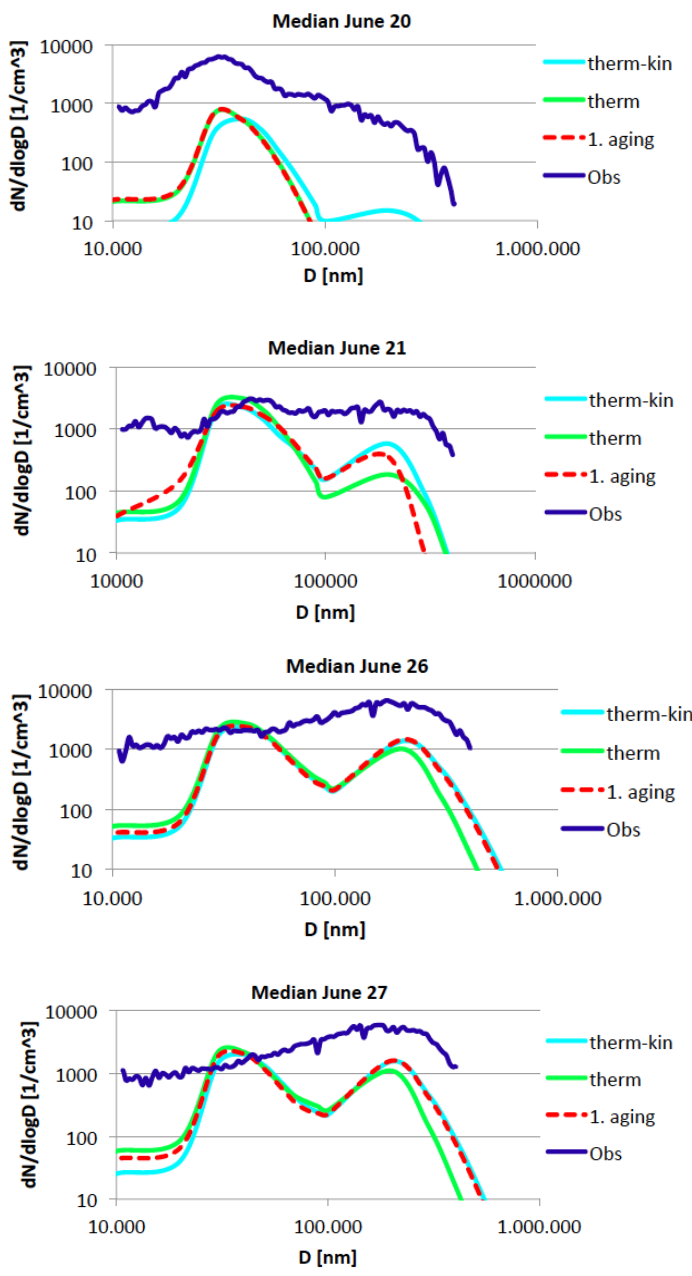

Fig. 7. Median dry aerosol number size distribution $\left[\mathrm{cm}^{-3}\right]$ at Puyde-Dôme for fresh air masses (20 and 21 June) and aged air masses (26 and 27 June). Blue line: measured median; light blue line: modelled daytime median with the thermodynamic-kinetic approach and $10 \%$ aging; green line: modelled daytime median with the pure thermodynamic approach; red line: modelled daytime median with the first aging step only in the thermodynamic-kinetic approach and $10 \%$ aging.

lower free troposphere, however, the particle number concentrations determined by the thermodynamic-kinetic approach in the Aitken and accumulation mode remain slightly smaller than those calculated with the thermodynamic approach. The reason is that nucleation is of increasing importance with increasing height in the thermodynamic-kinetic approach, thereby generating more nucleation mode particles.

The chosen episode is unfortunately not suitable to study the role of LV-SOG nucleation, as nucleation events at Puyde-Dôme were rare during the period of observation. However, one nucleation event took place on 20 June, just before the intensive measurement campaign. Model simulation results of a sensitivity study with and without LV-SOG nucleation at Puy-de-Dôme are shown in Fig. 9. The nucleation event on 20 June was detected in the model results considering LV-SOG nucleation and in the measurements with SMPS. However, it was weak and without much implication, as precipitation reduces particle number concentrations considerably. Differences in the model results with and without LVSOG nucleation are visible in the lower free troposphere over several days of the period, where due to coagulation and condensational growth of nucleation and Aitken mode particles an increase of accumulation mode particles occurs when nucleation of LV-SOG is taken into account. As measured vertical profiles of particle number concentrations are not available at Puy-de-Dôme during the period investigated here, an evaluation of the model results was not possible. However, in a long-term study, Boulon et al. (2011) found favoured nucleation at Puy-de-Dôme compared to an adjacent station at lower altitude. Further studies will be necessary to highlight the role of LV-SOG nucleation in the PBL and lower free troposphere, and the role of this process for the formation of particles in the size range of cloud condensation nuclei (CCN) particles. Those studies should consider interactions between LV-SOG and $\mathrm{H}_{2} \mathrm{SO}_{4}$ as proposed by Kerminen et al. (2010), Metzger et al. (2010) and Paasonen et al. (2010).

\section{Conclusions and outlook}

A considerable increase in modelled SOA mass concentration at Puy-de-Dôme, France as measured during an intensive observation campaign in June 2010 was achieved by taking into account the aging processes of SOA precursor gases and thereby more realistically reproducing measured SOA concentrations. In contrast to the pure thermodynamic gasparticle partitioning approach usually applied for modelling SOA formation, we use a mixed thermodynamic-kinetic approach based on $\mathrm{Yu}$ (2011), which produced higher and more realistic SOA mass concentrations. During high-pressure periods in summer, as investigated here, biogenic VOC emissions play an important role for the formation of SOA. By using the mixed thermodynamic-kinetic approach for SOA formation, their overall uncertainty offers an explanation for the differences in measured and modelled SOA mass concentration at Puy-de-Dôme. This does not hold for the pure thermodynamic SOA formation mechanism, where modelled SOA aerosol mass concentrations remain far below the measurements even when biogenic VOC emissions are increased. Compared to pure thermodynamic SOA formation mechanisms, an increase of aerosols in the size range of CCN during a period with multiple nucleation events in the PBL is reported by Yu (2011). During the period investigated here, nucleation events in the PBL were rare, but a considerable increase in accumulation mode particle number concentration was determined with the mixed thermodynamic-kinetic approach in comparison to the pure thermodynamic one, in particular in fresh air masses. These results emphasise the inter-relationship of reliable SOA formation mechanism and 

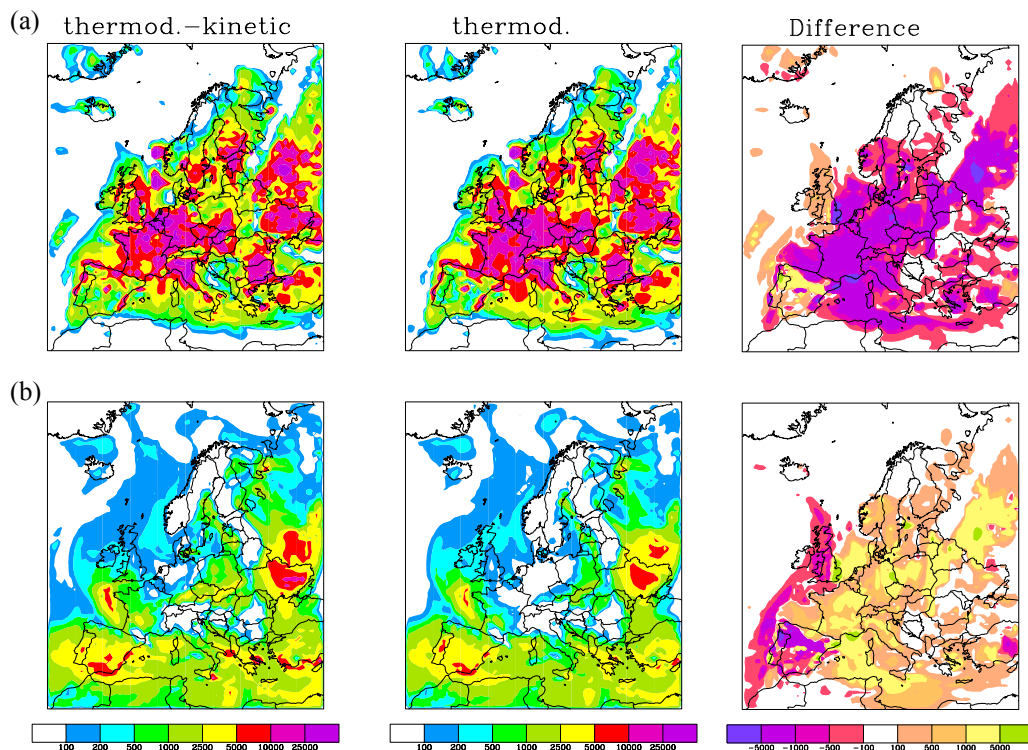

Fig. 8. Modelled near-surface particle number concentration $\left[\mathrm{cm}^{-3}\right]$ in (a) the Aitken and (b) the accumulation mode on 22 June 2010 , 18:00 UTC over Europe. The difference is determined by subtraction of the thermodynamic data from the mixed thermodynamic-kinetic data.

(a)

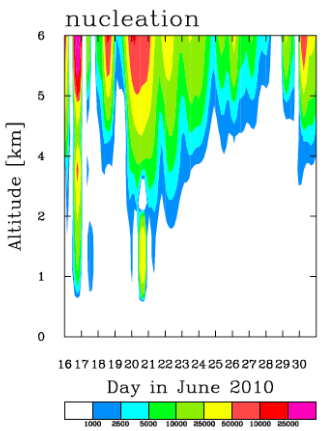

(b)

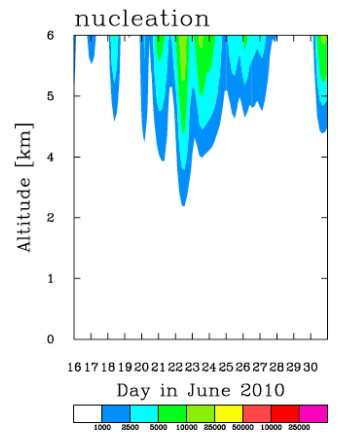

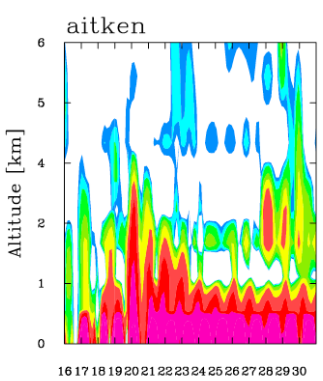

Day in June 2010
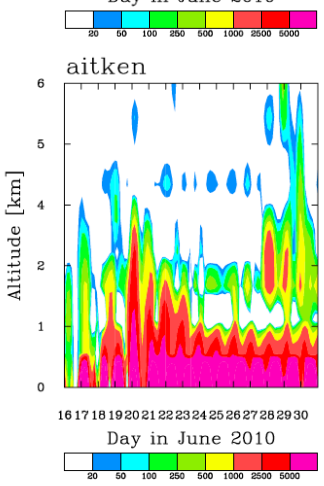
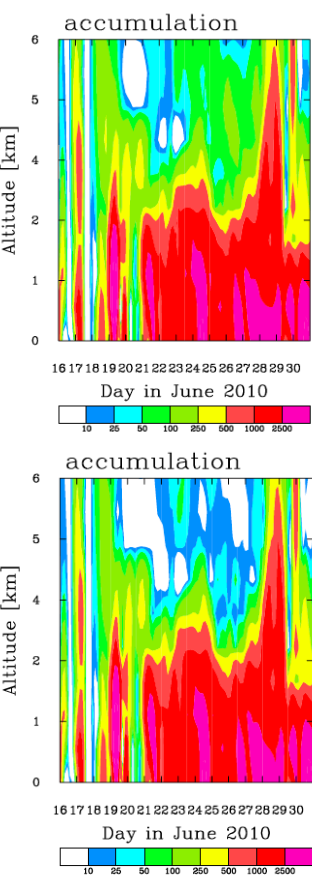

Fig. 9. Modelled vertical profiles of particle number concentration in the nucleation (left column), Aitken (middle column) and accumulation mode (right column) at Puy-de-Dôme in $\mathrm{cm}^{-3}$ during June 2010 (a) with LV-SOG nucleation and (b) without LV-SOG nucleation.

aerosol-cloud interactions for more realistic model simulation results concerning clouds and precipitation formation.

New developments considering hetero-molecular nucleation between $\mathrm{H}_{2} \mathrm{SO}_{4}$ and organic vapours have been published recently (Paasonen et al., 2010). Unfortunately, the period investigated here represents an unsuitable episode to in- vestigate co-nucleation of $\mathrm{H}_{2} \mathrm{SO}_{4}$ and organic vapours in the $\mathrm{PBL}$ due to the rare nucleation events taking place. Therefore further model application will be necessary to highlight the role of SOG nucleation.

In addition to aging processes of SOG and thermodynamic and kinetic SOA formation processes, other SOA formation 
processes are discussed in the literature, like SOA formation in the aqueous phase (Ervens et al., 2011) or new SOA particle formation on pre-existing ionised clusters (e.g. Zhang et al., 2011). For future investigations it is worth considering that Puy-de-Dôme, located in the mountainous area of the Massif Central in France, is known as a region of higher 222Rn surface concentration than the surrounding (Szegvary et al., 2009), thereby potentially offering a higher concentration of ionised clusters as sites for new SOA particle formation.

Furthermore, a deeper understanding of chemical mechanism contributing to the aging processes of secondary organic gases, such as fragmentation or oligomerisation reactions (Shrivastava et al., 2013), will be necessary to improve aging parameterisations for three-dimensional modelling.

Similar to other past and recent modelling studies on OC aerosols over Europe, the new SOA formation approach applied here is not able to reproduce measured OC aerosol concentrations during winter. Many indications point to underestimated amounts from residential wood burning in large parts of Europe (e.g. Bergström et al., 2012; Langmann et al., 2008; Gelencser et al., 2007; Szidat et al., 2007). Updated emission inventories need to take into account the changing heating practices in Europe and the use of wood burning not only in rural but also in urban areas.

\section{Supplementary material related to this article is available online at http://www.atmos-chem-phys.net/14/ 3831/2014/acp-14-3831-2014-supplement.pdf.}

Acknowledgements. The authors would like to thank the German and French Science Foundations DFG and CNRS for the joint funding of this work within the project ATMOCHEM - Secondary organic aerosol production in the lower free troposphere over Western Europe. The work has also been partly funded by the FP6 Integrated project EUCAARI, contract no. 36833. In addition, the availability of ECMWF analysis data is acknowledged.

Edited by: B. Ervens

\section{References}

Allan, J. D., Delia, A. E., Coe, H., Bower, K. N., Alfarra M. R., Jimenez, J. L., Middlebrook, A. M., Drewnick, F., Onasch, T. B., Canagaratna, M. R., Jayne, J. T., and Worsnop, D. R.: A generalised method for the extraction of chemically resolved mass spectra from aerodyne aerosol mass spectrometer data, J. Aerosol Sci., 35, 909-922, 2004.

Anttila, T., Langmann, B., Varghese, S., and O'Dowd, C.: Contribution of isoprene oxidation products to marine aerosol over the North-East Atlantic, Adv. Meteorol., 2010, 482603, doi:10.1155/2010/482603, 2010.

Bergström, R., Denier van der Gon, H. A. C., Prévôt, A. S. H., Yttri, K. E., and Simpson, D.: Modelling of organic aerosols over Europe (2002-2007) using a volatility basis set (VBS) framework: application of different assumptions regarding the formation of secondary organic aerosol, Atmos. Chem. Phys., 12, 8499-8527, doi:10.5194/acp-12-8499-2012, 2012.

Boulon, J., Sellegri, K., Hervo, M., Picard, D., Pichon, J.-M., Fréville, P., and Laj, P.: Investigation of nucleation events vertical extent: a long term study at two different altitude sites, Atmos. Chem. Phys., 11, 5625-5639, doi:10.5194/acp-11-56252011, 2011.

Canagaratna, M. R., Jayne, J. T., Jimenez, J. L., Allan, J. D., Alfarra, M. R., Zhang, Q., Onasch, T. B., Drewnick, F., Coe, H., Middlebrook, A., Delia, A., Williams, L. R., Trimborn, A. M., Northway, M. J., DeCarlo, P. F., Kolb, C. E., Davidovits, P., and Worsnop, D. R.: Chemical and microphysical characterization of ambient aerosols with the aerodyne aerosol mass spectrometer, Mass Spectrom. Rev., 26, 185-222, 2007.

D’Andrea, S. D., Häkkinen, S. A. K., Westervelt, D. M., Kuang, C., Levin, E. J. T., Kanawade, V. P., Leaitch, W. R., Spracklen, D. V., Riipinen, I., and Pierce, J. R.: Understanding global secondary organic aerosol amount and size-resolved condensational behavior, Atmos. Chem. Phys., 13, 11519-11534, doi:10.5194/acp-1311519-2013, 2013.

Drewnick, F., Hings, S. S., DeCarlo, P., Jayne, J. T., Gonin, M., Fuhrer, K., Weimer, S., Jimenez, J. L., Demerjian, K. L., Borrmann, S., and Worsnop, D. R.: A New Time-of-Flight Aerosol Mass Spectrometer (TOF-AMS)-Instrument Description and First Field Deployment, Aerosol Sci. Tech., 39, 637-658, 2005.

Ervens, B., Turpin, B. J., and Weber, R. J.: Secondary organic aerosol formation in cloud droplets and aqueous particles (aqSOA): a review of laboratory, field and model studies, Atmos. Chem. Phys., 11, 11069-11102, doi:10.5194/acp-1111069-2011, 2011.

Freney, E. J., Sellegri, K., Canonaco, F., Boulon, J., Hervo, M., Weigel, R., Pichon, J. M., Colomb, A., Prévôt, A. S. H., and Laj, P.: Seasonal variations in aerosol particle composition at the puy-de-Dôme research station in France, Atmos. Chem. Phys., 11, 13047-13059, doi:10.5194/acp-11-13047-2011, 2011.

Fiedler, V., Dal Maso, M., Boy, M., Aufmhoff, H., Hoffmann, J., Schuck, T., Birmili, W., Hanke, M., Uecker, J., Arnold, F., and Kulmala, M.: The contribution of sulphuric acid to atmospheric particle formation and growth: a comparison between boundary layers in Northern and Central Europe, Atmos. Chem. Phys., 5, 1773-1785, doi:10.5194/acp-5-1773-2005, 2005.

Gantt, B., Meskhidze, N., Facchini, M. C., Rinaldi, M., Ceburnis, D., and O'Dowd, C. D.: Wind speed dependent size-resolved parameterization for the organic mass fraction of sea spray aerosol, Atmos. Chem. Phys., 11, 8777-8790, doi:10.5194/acp-11-87772011, 2011.

Gelencser, A., May, B., Simpson, D., Sanchez-Ochoa, A., Kasper-Giebl, A., Puxbaum, H., Caseiro, A., Pio, C., and Legrand, M.: Source apportionment of PM2.5 organic aerosol over Europe: primary/secondary, natural/anthropogenic, fossil/biogenic origin, J. Geophys. Res., 112, D23S04, doi:10.1029/2006JD008094, 2007.

Griffin, R. J., Dabdub, D., and Seinfeld, J. H.: Secondary organic aerosol. I. Atmospheric chemical mechanism for production of molecular constituents, J. Geophys. Res., 107, 4332, doi:10.1029/2001JD000541, 2002. 
Guenther, A. B., Monson, R. K., and Fall, R.: Isoprene and monoterpene emission rate variability: observations with eucalyptus and emission rate algorithm development, J. Geophys. Res., 96, 10799-10808, 1991.

Guenther, A. B., Zimmermann, P. R., Harley, P. C., Monson, R. K., and Fall, R.: Isoprene and monoterpene emission rate variability: model evaluation and sensitivity analysis. J. Geophys. Res., 98, 12609-12617, 1993.

Hallquist, M., Wenger, J. C., Baltensperger, U., Rudich, Y., Simpson, D., Claeys, M., Dommen, J., Donahue, N. M., George, C., Goldstein, A. H., Hamilton, J. F., Herrmann, H., Hoffmann, T., Iinuma, Y., Jang, M., Jenkin, M. E., Jimenez, J. L., Kiendler-Scharr, A., Maenhaut, W., McFiggans, G., Mentel, Th. F., Monod, A., Prévôt, A. S. H., Seinfeld, J. H., Surratt, J. D., Szmigielski, R., and Wildt, J.: The formation, properties and impact of secondary organic aerosol: current and emerging issues, Atmos. Chem. Phys., 9, 5155-5236, doi:10.5194/acp-9-51552009, 2009.

Hamed, A., Birmili, W., Joutsensaari, J., Mikkonen, S., Asmi, A., Wehner, B., Spindler, G., Jaatinen, A., Wiedensohler, A., Korhonen, H., Lehtinen, K. E. J., and Laaksonen, A.: Changes in the production rate of secondary aerosol particles in Central Europe in view of decreasing $\mathrm{SO}_{2}$ emissions between 1996 and 2006, Atmos. Chem. Phys., 10, 1071-1091, doi:10.5194/acp-10-10712010, 2010.

Heald, C. L., Jacob, D. J., Park, R. J., Russell, L. M., Hubert, B. J., Seinfeld, J. H., Liao, H., and Weber, R.J.: A large organic aerosol source in the free troposphere missing from current models, Geophys. Res. Lett., 32, L18809, doi:10.1029/2005GL023831, 2005.

Henne, S., Brunner, D., Folini, D., Solberg, S., Klausen, J., and Buchmann, B.: Assessment of parameters describing representativeness of air quality in-situ measurement sites, Atmos. Chem. Phys., 10, 3561-3581, doi:10.5194/acp-10-3561-2010, 2010.

Henze, D. K. and Seinfeld, J. H.: Global secondary organic aerosol from isoprene oxidation, Geophys. Res. Lett., 33, L09812, doi:10.1029/2006GL025976, 2006.

Hodzic, A., Jimenez, J. L., Madronich, S., Canagaratna, M. R., DeCarlo, P. F., Kleinman, L., and Fast, J.: Modeling organic aerosols in a megacity: potential contribution of semi-volatile and intermediate volatility primary organic compounds to secondary organic aerosol formation, Atmos. Chem. Phys., 10, 5491-5514, doi:10.5194/acp-10-5491-2010, 2010.

Jimenez, J. L., Canagaratna, M. R., Donahue, N. M., Prevot, A. S. H., Zhang, Q., Kroll, J. H., DeCarlo, P. F., Allan, J. D., Coe, H., Ng, N. L., Aiken, A. C., Docherty, K. S., Ulbrich, I. M., Grieshop, A. P., Robinson, A. L., Duplissy, J., Smith, J. D., Wilson, K. R., Lanz, V. A., Hueglin, C., Sun, Y. L., Tian, J., Laaksonen, A., Raatikainen, T., Rautiainen, J., Vaattovaara, P., Ehn, M., Kulmala, M., Tomlinson, J. M., Collins, D. R., Cubison, M. J., Dunlea, E. J., Huffman, J. A., Onasch, T. B., Alfarra, M. R., Williams, P. I., Bower, K., Kondo, Y., Schneider, J., Drewnick, F., Borrmann, S., Weimer, S., Demerjian, K., Salcedo, D., Cottrell, L., Griffin, R., Takami, A., Miyoshi, T., Hatakeyama, S., Shimono, A., Sun, J. Y., Zhang, Y. M., Dzepina, K., Dzepina, K., Kimmel, J. R., Sueper, D., Jayne, J. T., Herndon, S. C., Trimborn, A. M., Williams, L. R., Wood, E. C., Middlebrook, A. M., Kolb, C. E., Baltensperger, U., and Worsnop, D. R.: Evolution of organic aerosols in the atmosphere, Science, 326, 1525-1529, 2009 .
Kasper-Giebl, A., Koch, A., Hitzenberger R., and Puxbaum, H.: Scavenging efficiency of aerosol carbon and sulfate in supercooled clouds at Mt. Sonnblick (3106 m a.s.1, Austria), J. Atmos. Chem., 35, 33-46, 2000.

Kerminen, V.-M., Petäjä, T., Manninen, H. E., Paasonen, P., Nieminen, T., Sipilä, M., Junninen, H., Ehn, M., Gagné, S., Laakso, L., Riipinen, I., Vehkamäki, H., Kurten, T., Ortega, I. K., Dal Maso, M., Brus, D., Hyvärinen, A., Lihavainen, H., Leppä, J., Lehtinen, K. E. J., Mirme, A., Mirme, S., Hõrrak, U., Berndt, T., Stratmann, F., Birmili, W., Wiedensohler, A., Metzger, A., Dommen, J., Baltensperger, U., Kiendler-Scharr, A., Mentel, T. F., Wildt, J., Winkler, P. M., Wagner, P. E., Petzold, A., Minikin, A., Plass-Dülmer, C., Pöschl, U., Laaksonen, A., and Kulmala, M.: Atmospheric nucleation: highlights of the EUCAARI project and future directions, Atmos. Chem. Phys., 10, 10829-10848, doi:10.5194/acp-10-10829-2010, 2010.

Kroll, J. H. and Seinfeld, J. H.: Chemistry of secondary organic aerosol: Formation and evolution of low-volatility organics in the atmosphere, Atmos. Environ., 42, 3593-3624, 2008.

Langmann, B.: Numerical modeling of regional scale transport and photochemistry directly together with meteorological processes, Atmos. Environ., 34, 3585-3598, 2000.

Langmann, B., Bauer, S. E., and Bey, I.: The influence of the global photochemical composition of the troposphere on European summer smog, Part I: Application of a global to mesoscale model chain, J. Geophys. Res., 108, 4146, doi:10.1029/2002JD002072, 2003.

Langmann, B., Varghese, S., Marmer, E., Vignati, E., Wilson, J., Stier, P., and O'Dowd, C.: Aerosol distribution over Europe: a model evaluation study with detailed aerosol microphysics, Atmos. Chem. Phys., 8, 1591-1607, doi:10.5194/acp-8-1591-2008, 2008.

Madronich, S.: Photodissociation in the atmosphere. 1. Actinic flux and the effect of ground reflections and clouds, J. Geophys. Res. 92, 9740-9752, 1987.

Majewski, D.: The Europa Modell of the Deutscher Wetterdienst, Seminar Proceedings ECMWF, ECMWF Shinfield Park, Reading, Berks, UK, Vol. 2, 147-191, 1991.

Marmer E. and Langmann, B.: Aerosol modelling over Europe Part I: Inter-annual variability of aerosol distribution, J. Geophys. Res., 112, D23S15, doi:10.1029/2006JD008113, 2007.

Mellor, B. and Yamada, T.: A hierarchy of turbulence closure models for planetary boundary layers, J. Atmos. Sci., 31, 1791-1806, 1974.

Metzger, A., Verheggen, B., Dommen, J., Duplissy, J., Prevot, A. S. H., Weingartner, E., Riipinen, I., Kulmala, M., Spracklen, D. V., Carslaw, K. S., and Baltensperger, U.: Evidence for the role of organics in aerosol particle formation under atmospheric conditions, P. Natl. Acad. Sci. USA, 107, 6646-6651, 2010.

O’Dowd, C., Langmann, B., Varghese, S., Scannell, C., Ceburnis, D., and Facchini, M. C.: A combined organic-inorganic sea-spray source function, Geophys. Res. Lett., 35, L01801, doi:10.1029/2007GL030331, 2008.

Odum, J. R., Hoffmann, T., Bowman, F., Collins, D., Flagan, R. C., and Seinfeld, J. H.: Gas/particle partitioning and secondary organic aerosol yields, Environ. Sci. Technol., 30, 2580-2585, 1996.

Ovadnevaite, J., Ceburnis, D., Canagaratna, M., Berresheim, H., Bialek, J., Mrtucci, G., Worsnop, D. R., and O’Dowd, C.: On 
the effect of wind speed on submicron sea salt mass concentration and source fluxes, J. Geophys. Res., 117, D16201, doi:10.1029/2011JD017379, 2012.

Paasonen, P., Nieminen, T., Asmi, E., Manninen, H. E., Petäjä, T., Plass-Dülmer, C., Flentje, H., Birmili, W., Wiedensohler, A., Hõrrak, U., Metzger, A., Hamed, A., Laaksonen, A., Facchini, M. C., Kerminen, V.-M., and Kulmala, M.: On the roles of sulphuric acid and low-volatility organic vapours in the initial steps of atmospheric new particle formation, Atmos. Chem. Phys., 10, 11223-11242, doi:10.5194/acp-10-11223-2010, 2010.

Pankow, J. F.: An absorption model of the gas/aerosol partitioning involved in the formation of secondary organic aerosol, Atmos. Environ., 28, 189-193, 1994.

Riipinen, I., Pierce, J. R., Yli-Juuti, T., Nieminen, T., Häkkinen, S., Ehn, M., Junninen, H., Lehtipalo, K., Petäjä, T., Slowik, J., Chang, R., Shantz, N. C., Abbatt, J., Leaitch, W. R., Kerminen, V.-M., Worsnop, D. R., Pandis, S. N., Donahue, N. M., and Kulmala, M.: Organic condensation: a vital link connecting aerosol formation to cloud condensation nuclei $(\mathrm{CCN})$ concentrations, Atmos. Chem. Phys., 11, 3865-3878, doi:10.5194/acp-11-38652011, 2011.

Robinson, A. L., Donahue, N. M., Shrivastava, M. K., Weitkamp, E. A., Sage, A. M., Grieshop, A. P., Lane, T. E., Pierce, J. R., and Pandis, S. N.: Rethinking organic aerosols: Semivolatile emissions and photochemical aging, Science, 315, 1259-1262, doi:10.1126/science.1133061, 2007.

Roeckner, E., Arpe, K., Bengtsson, L., Christoph, M., Claussen, M., Dümenil, L., Esch, M., Giorgetta, M., Schlese U., and Schulzweida, U.: The atmospheric general circulation model ECHAM-4: Model description and simulation of present-day climate, MPI-Report No. 218, Max Planck Institute for Meteorology, Hamburg, Germany, 1996.

Saxena, P. and Hildemann, L. M.: Water-soluble organics in atmospheric particles: a critical review of the literature and application of thermodynamics to identify candidate compounds, J. Atmos. Chem., 24, 57-109, 1996.

Shrivastava, M., Lane, T. E., Donahue, N. M., Pandis, S. N., and Robinson, A. L.: Effects of gas particle partitioning and aging of primary emissions on urban and regional organic aerosol concentrations, J. Geophys. Res., 113, D18301, doi:10.1029/2007JD009735, 2008.

Shrivastava, M., Fast, J., Easter, R., Gustafson Jr., W. I., Zaveri, R. A., Jimenez, J. L., Saide, P., and Hodzic, A.: Modeling organic aerosols in a megacity: comparison of simple and complex representations of the volatility basis set approach, Atmos. Chem. Phys., 11, 6639-6662, doi:10.5194/acp-11-6639-2011, 2011.

Shrivastava, M., Zelenyuk, A., Imre, D., Easter, R., Beranek, J., Zaveri, R. A., and Fast, J.: Implications of low volatility SOA and gas-phase fragmentation reactions on SOA loadings and their spatial and temporal evolution in the atmosphere, J. Geophys. Res., 118, 3328-3342, doi:10.1002/jgrd.50160, 2013.

Smolarkiewitz, P. K.: A simple positive definite advection scheme with small implicit diffusion, Mon. Weather Rev., 111, 479-486, 1983.
Stier, P., Feichter, J., Kinne, S., Kloster, S., Vignati, E., Wilson, J., Ganzeveld, L., Tegen, I., Werner, M., Balkanski, Y., Schulz, M., Boucher, O., Minikin, A., and Petzold, A.: The aerosol-climate model ECHAM5-HAM, Atmos. Chem. Phys., 5, 1125-1156, doi:10.5194/acp-5-1125-2005, 2005.

Stockwell, W. R., Middleton, P., Chang, J. S., and Tang, X.: The second generation regional acid deposition model: chemical mechanism for regional air quality modelling, J. Geophys. Res., 95, 16343-16367, 1990.

Szegvary, T., Conen, F., and Ciais, P.: European 222Rn inventory for applied atmospheric studies, Atmos. Environ., 43, 1536-1539, 2009.

Szidat, S., Prevot, A. S. H., Sandradewi, J., Sandradewi, J., Alfarra, M. R., Synal, H.-A., Wacker, L., and Baltensperger, U.: Dominant impact of residential wood burning on particulate matter in Alpine valleys during winter, Geophys. Res. Lett., 34, L05820, doi:10.1029/2006GL028325, 2007.

Tiedtke, M.: A comprehensive mass flux scheme for cumulus parameterisation in large-scale models, Mon. Weather Rev., 117, 1778-1800, 1989.

Vehkamäki, H., Kumala, M., Napari, I., Lehtinen, K. E. J., Timmreck, C., Noppel, M., and Laaksonen, A.: An improved parameterization for sulphuric acid-water nucleation rates for tropospheric and stratospheric conditions, J. Geophys. Res., 107, 4622, doi:10.1029/2002JD002184, 2002.

Venzac, H., Sellegri, K., Villani, P., Picard, D., and Laj, P.: Seasonal variation of aerosol size distributions in the free troposphere and residual layer at the puy de Dôme station, France, Atmos. Chem. Phys., 9, 1465-1478, doi:10.5194/acp-9-1465-2009, 2009.

Vignati, E., Wilson, J., and Stier, P.: M7, An efficient size-resolved aerosol microphysics module for large-scale aerosol transport models, J. Geophys. Res., 109, D22202, doi:10.1029/2003JD004485, 2004.

Walcek, C. J. and Taylor, G. R.: A theoretical method for computing vertical distributions of acidity and sulfate production within cumulus clouds, J. Atmos. Sci., 43, 339-355, 1986.

Wesley, M. L.: Parameterization of surface resistances to gaseous dry deposition in regional-scale numerical models, Atmos. Environ., 23, 1293-1304, 1989.

Yu, F.: A secondary organic aerosol formation model considering successive oxidation aging and kinetic condensation of organic compounds: global scale implications, Atmos. Chem. Phys., 11, 1083-1099, doi:10.5194/acp-11-1083-2011, 2011.

Zhang, K., Feichter, J., Kazil, J., Wan, H., Zhuo, W., Griffiths, A. D., Sartorius, H., Zahorowski, W., Ramonet, M., Schmidt, M., Yver, C., Neubert, R. E. M., and Brunke, E.-G.: Radon activity in the lower troposphere and its impact on ionization rate: a global estimate using different radon emissions, Atmos. Chem. Phys., 11, 7817-7838, doi:10.5194/acp-11-7817-2011, 2011.

Zhang, X., Pandis, S. N., and Seinfeld, J. H.: Diffusion-Limited vs. Quasi-Equilibrium Aerosol Growth, Aerosol Sci. Tech., 46, 874 885, 2012. 